\title{
Characterization of four Escherichia albertii isolates collected from animals living in Antarctica and Patagonia
}

\author{
Linda GRILLOVÁ1), Ivo SEDLÁČEK ${ }^{2)}$, Gabriela PÁCHNÍKOVÁ ${ }^{1)}$, Eva STAŇKOVÁ2), \\ Pavel ŠVEC ${ }^{2)}$, Pavla HOLOCHOVÁ2), Lenka MICENKOVÁ ${ }^{3)}$, Juraj BOSÁK ${ }^{1)}$, \\ Iva SLANINOVÁ ${ }^{1)}$ and David ŠMAJS ${ }^{1) *}$ \\ 1)Department of Biology, Faculty of Medicine, Masaryk University, 625 00, Brno, Czech Republic \\ ${ }^{2)}$ Czech Collection of Microorganisms, Department of Experimental Biology, Faculty of Science, Masaryk \\ University, 625 00, Brno, Czech Republic \\ ${ }^{3)}$ Research Centre for Toxic Compounds in the Environment, Faculty of Science, Masaryk University, 62500 , \\ Brno, Czech Republic
}

\section{J. Vet. Med. Sci. \\ 80(1): 138-146, 2018}

doi: 10.1292/jvms.17-0492

Received: 4 September 2017

Accepted: 17 November 2017 Published online in J-STAGE: 15 December 2017
ABSTRACT. Escherichia albertii is a recently discovered species with a limited number of well characterized strains. The aim of this study was to characterize four of the E. albertii strains, which were among 41 identified Escherichia strains isolated from the feces of living animals on James Ross Island, Antarctica, and Isla Magdalena, Patagonia. Sequencing of 16S rDNA, automated ribotyping, and rep-PCR were used to identify the four E. albertii isolates. Phylogenetic analyses based on multi-locus sequence typing showed these isolates to be genetically most similar to the members of E. albertii phylogroup G3. These isolates encoded several virulence factors including those, which are characteristic of E. albertii (cytolethal distending toxin and intimin) as well as bacteriocin determinants that typically have a very low prevalence in $E$. coli strains (D, E7). Moreover, E. albertii protein extracts caused cell cycle arrest in human cell line A375, probably because of cytolethal distending toxin activity.

KEY WORDS: Antarctica, bacteriocins, cytolethal distending toxin, Escherichia albertii

Strains of Escherichia albertii were originally classified as Hafnia alvei-like stains, which were isolated from human stool specimens in the early 1990s and were suspected of being causative agents of diarrhea [1]. Based on DNA-DNA hybridization analyses, the Hafnia alvei-like strains were reclassified as a new species-Escherichia albertii [15]. Even though E. albertii is a relative of $E$. coli, it is phylogenetically distinct from other Escherichia species [16, 23, 37, 56].

In general, Escherichia albertii is a potential human pathogen with a limited number of characterized isolates. Since 2003, when the new E. albertii species was proposed, only 282 isolates have been described and more than half of them (n=144) were associated with diarrhea and/or gastroenteritis in humans $[2,3,6,9,10,13-15,17,20,21,24,25,31-35,37,42,52,55-57]$. E. albertii has also been shown to be responsible for epidemic mortality among birds [33]. It has been isolated from pig, cat, environmental samples, and found as a contaminant of various raw meats [14, 23, 33, 36, 42, 57].

However, the real frequency of $E$. albertii in clinical samples remains unclear. E. albertii ferments D-mannitol but not D-xylose and does not produce indole. Because strains of $E$. albertii are not included in the databases of majority of commercial diagnostic tests, E. albertii strains are often misidentified as Hafnia, Salmonella, Escherichia coli or Yersinia ruckeri [reviewed in 59]. $E$. albertii possesses a specific set of virulence genes including intimin and the eae-encoded outer membrane protein, and thus many strains of E. albertii might be misidentified as enterohemorrhagic (EHEC) or enteropathogenic E. coli (EPEC) [36, 58]. However, compared to the EPEC (and not EHEC), E. albertii often encodes cytolethal distending toxin that causes cell cycle arrest in eukaryotic cells, which leads to cell distention and cell death $[4,8,16,46,60]$.

Escherichia species, as well as many other bacterial species, are known to produce antimicrobial agents called bacteriocins. In the genus Escherichia, bacteriocins include colicins and microcins. Although the exact role of bacteriocin production in bacterial populations remains unclear, there is increasing evidence of the role of bacteriocins in bacterial virulence [28, 49], in probiotic phenotype of E. coli strains [50], and in colonization of the gastrointestinal tract [11].

Recently, we isolated E. albertii from feces of Antarctic animals and published preliminary data regarding characterization [44]. In this work, we have analyzed a larger sample set of isolates and characterized, in greater detail, four isolates of $E$. albertii from

*Correspondence to: Šmajs, D.: dsmajs@med.muni.cz

O2018 The Japanese Society of Veterinary Science

This is an open-access article distributed under the terms of the Creative Commons Attribution Non-Commercial No Derivatives (by-nc-nd) License. (CC-BY-NC-ND 4.0: https://creativecommons.org/licenses/by-nc-nd/4.0/) 
animals living in Antarctica and Patagonia.

\section{MATERIALS AND METHODS}

\section{Samples collection}

Fecal specimens and rectal or cloacal swabs from seals (mostly Leptonychotes weddelli), penguins (Pygoscelis adeliae, P. papua, Spheniscus magellanicus), skuas (Stercorarius maccormicki), and gulls (Larus dominicanus) were collected on James Ross Island and Seymour Island, Antarctica, and Isla Magdalena, Patagonia, during austral summers in 2013 and 2014. This sampling was a part of Cultivable Fecal Bacteria Communities study, which was part of the CzechPolar project. The samples were collected using swab/transport tube system E-Swabs (Dispolab, Brno, Czech Republic), kept at $4^{\circ} \mathrm{C}$ and transported to the Czech Republic for further analyses.

Reference and type strains used in this study were obtained from the Czech Collection of Microorganisms (Masaryk University, Brno, Czech Republic).

\section{Isolation and biochemical identification of strains}

Samples were cultivated on Columbia blood agar and sub-cultivated on Columbia blood agar supplemented with $7 \%$ sheep blood (Bio-Rad, Praha, Czech Republic) at $30^{\circ} \mathrm{C}$ for $24 \mathrm{hr}$. Different colonies revealing the macroscopic morphology typical for enteric bacteria were randomly picked up from smears of faecal samples grown on Endo agar and MacConkey agar. Two commercial identification kits, ENTEROtest 24 (Erba Lachema, Brno, Czech Republic) and Biolog Identification System, GN2 MicroPlate (Biolog, Hayward, CA, U.S.A.), were used (according to the manufacturers' instructions). The list of 41 identified Escherichia isolates is shown in Table S1.

\section{S rDNA and multi-locus sequence typing (MLST) analyses}

The 16S rRNA gene, from all 41 Escherichia isolates, was amplified as described previously [41]. Additionally, a MLST analysis of E. albertii isolates was performed by amplifying and sequencing six housekeeping genes, $a s p \mathrm{C}$, clpX, $f a d \mathrm{D}, i c d \mathrm{~A}, \operatorname{lys} \mathrm{P}$ and $m d h$, using a previously described protocol $[16,33]$. All PCR products were sequenced using the Sanger method (Elisabeth ${ }^{\circledR}$ Pharmacon, Brno, Czech Republic and GATC Biotech AG, Konstanz, Germany). Sequences were analyzed using Lasergene software (DNASTAR v.7.1.0., Madison, WI, U.S.A.).

\section{Automated ribotyping, repetitive element PCR (rep-PCR) and pulse-field gel electrophoresis (PFGE)}

All 41 isolates, which had been previously classified to the Escherichia genus by commercial identification kits, were used for automated ribotyping with the EcoRI restriction enzyme and rep-PCR fingerprinting as described previously [53, 54]. PFGE was performed using the XbaI enzyme and the standardized PulseNet protocol for E. coli O157:H7 (http://www.pulsenetinternational. org/protocols). The dendrograms of automated ribotyping and rep-PCR were constructed with Pearson's correlation coefficient and analysis of PFGE macrorestriction patterns was done with Jaccard similarity coefficient. All dendrograms were constructed with UPGMA clustering method (BioNumerics v. 7.5, Applied Maths, Sint-Martens-Latem, Belgium).

\section{$P C R$ detection of virulence markers}

Our set of E. albertii isolates and the E. albertii type strain, CCM $7160^{\mathrm{T}}$, were tested for the presence of 21 virulence markers, which are typical for the Enterobacteriaceae. This included genes encoding virulence factors found in enteroaggregative $E$. coli (pCVD432), enterotoxigenic $E$. coli (heat-labile enterotoxin $(l t)$ and heat-stable enterotoxin (st)), enteroinvasive $E$. coli (invasivity antigen (ial) and invasion plasmid antigen $\mathrm{H}(i p a \mathrm{H})$ ), enteropathogenic $E$. coli (colibactin, bundle-forming pillus A $(b f p \mathrm{~A})$ and intimin (eaeA)), enterohemorrhagic E. coli (enterohemolysin (ehly) and Shiga toxins (stxl, stx2)), diffusely adherent $E$. coli (afimbrial adhesin $(a f a))$ and other genes coding virulence factors $(\alpha$-hemolysin $(\alpha-h l y)$, aerobactin $(a e r), \mathrm{B}$ unit of the cytolethal distending toxin $(c d t \mathrm{~B})$, cytotoxic necrosis factor $1(c n f 1)$, type I fimbriae (fim $\mathrm{A})$, aerobactin iron transport system (iucC), P-fimbriae (pap), S-fimbriae ( $s f a$ ) and uropathogenic specific protein $(u s p)$ ). The primer pair sequences, PCR product lengths and PCR protocols were previously described [5, 19, 22, 24, 26, 38, 39, 43, 59].

\section{Bacteriocin production and identification of bacteriocin types}

Detection of bacteriocin production was performed phenotypically as described previously [49] using bacteriocin indicator strains E. coli K12 - Row, E. coli C6 ( $\varphi$ ), Shigella sonnei 17, E. coli P400, E. coli S40 and E. coli 5K. For characterization of individual bacteriocin types, PCR amplifications of bacteriocin determinants were performed as described previously [28]. This screening detected most of the known colicins and microcin determinants $(n=32)$. The bacteriocin 'control' producers, used for PCR detection of bacteriocin genes, were previously described in a detail [27, 49].

\section{Whole protein extraction}

E. albertii strains examined in this study, E. albertii type strain CCM $7160^{\mathrm{T}}$, and E. coli CCM 4825 (K12) were grown overnight at $37^{\circ} \mathrm{C}$ in $3 \mathrm{ml}$ of TY broth (Himedia, Mumbai, India) and centrifugated at 5,000 $\mathrm{g}$ for $10 \mathrm{~min}$. Total bacterial proteins from 1 $\mathrm{g}$ of wet bacterial biomass were extracted using B-PER Complete bacterial protein extraction reagent (Thermo Fisher Scientific, Waltham, MA, U.S.A.) according to the manufacturer's recommendations. Final suspension was filtered using $0.45 \mu \mathrm{m}$ bacterial 
Table 1. Characteristics of Escherichia albertii isolates analyzed in this study

\begin{tabular}{|c|c|c|c|c|c|}
\hline Isolate & Source & $\begin{array}{l}\text { Similarity level } \\
-16 \mathrm{~S} \text { rDNA }(\%)^{\mathrm{a})}\end{array}$ & MLST $^{\mathrm{b})}$ & $\begin{array}{l}\text { Detected virulence } \\
\text { factor determinants }\end{array}$ & $\begin{array}{c}\text { Detected bacteriocin } \\
\text { determinants }\end{array}$ \\
\hline $\mathrm{P} 4652$ & Seal, Antarctica & 99.6 & $99.99 \%$ similarity to E. albertii in Corvus $\mathrm{sp}$. & $e a e, c d t \mathrm{~B}$, iuc $\mathrm{C}$ & $\mathrm{D}, \mathrm{E} 7$ \\
\hline P4653 & Seal, Antarctica & 99.6 & $99.99 \%$ similarity to E. albertii in Corvus sp. & $e a e, c d t \mathrm{~B}, i u c \mathrm{C}$ & D, E7 \\
\hline P4740 & Seal, Antarctica & 99.6 & $99.99 \%$ similarity to E. albertii in Corvus sp. & $e a e, c d t \mathrm{~B}, f i m \mathrm{~A}$ & $\mathrm{D}, \mathrm{E} 7$ \\
\hline P5661 & Penguin, Patagonia & 99.7 & Identical to E. albertii in Egretta garzetta & eae, $c d t \mathrm{~B}$, aer, fimA, ipaH & $\mathrm{B}, \mathrm{M}$ \\
\hline
\end{tabular}

a) Similarity was calculated according to the number of single nucleotide variants in $16 \mathrm{~S}$ rDNA sequences of E. albertii isolates compared to the 16S rDNA sequence of E. albertii type strain CCM $7160^{\mathrm{T}}$ (according to GenBank Accession No. AJ508775 in coordinates 58-1409). b) MLST - Multi Locus Sequence Typing based on six concatenated housekeeping genes ( $\operatorname{asp} C, \operatorname{clpX}$, fadD, icdA, lys $P$ and $m d h$ ). MLST data were compared to the data published in [37].

filters (Nalgene filters, Thermo Fisher Scientific, Waltham, MA, U.S.A.).

\section{Cultivation of cell line A375}

The human malignant melanoma cancer cell line, A375 (European Collection of Cell Cultures, Salisbury, U.K.), was used. Cells were grown in RPMI 1640 medium (HyClone Laboratories, Inc., South Logan, UT, U.S.A.) supplemented with 2 mmol $l^{-1} \mathrm{~L}$-glutamine (PAA Laboratories, Pasching, Austria), $10 \%$ fetal calf serum, penicillin (final concentration of $100 \mathrm{IU} \mathrm{m} l^{-1}$ ), and streptomycin (final concentration of $100 \mu \mathrm{g} \mathrm{m} l^{-1}$ ). Cells were incubated at $37^{\circ} \mathrm{C}$ under $5 \% \mathrm{CO}_{2}$ in a high-humidity-atmosphere and subcultured three times per week.

\section{Cell cycle analysis}

A375 cells were plated in concentration of $7 \times 10^{4}$ cells per $\mathrm{m} l$ and cultivated for 24 and $48 \mathrm{hr}$. Subsequently, A375 cells were treated with protein extracts (final dilution 1:1,000) for 24 and $48 \mathrm{hr}$. Both detached and attached cells were harvested into ice-cold PBS, fixed and processed as described previously [47]. A Cytomics FC 500 flow cytometry system (Beckman Coulter, Inc., Prague, Czech Republic) was used for cell cycle analysis. The cell cycle phases were determined using a Multicycle AV for Windows software (Phoenix Flow system, San Diego, CA, U.S.A.).

\section{RESULTS}

\section{Identification of Escherichia isolates}

As a part of Cultivable Fecal Bacteria Communities study project, we collected, during 2013-2014, 83 swabs of fecal specimens of randomly sampled animals from James Ross (23 seals, 14 penguins and 20 undetermined feces) and Seymour Islands (10 seals and 14 penguins), Antarctica, and Isla Magdalena, Patagonia (two penguins). From eight phenotypically identified genera of enteric bacteria (Aeromonas, Citrobacter, Edwardsiella, Enterobactre, Escherichia, Leclercia, Raoultella and Serratia), 41 isolates were classified as members of the Escherichia genus using two commercial identification kits, ENTEROtest 24 and Biolog GN2 MicroPlate system. This set of Escherichia strains was isolated from perianal or cloacal smears of seals $(\mathrm{n}=14)$, penguins $(\mathrm{n}=13)$, skuas $(\mathrm{n}=8)$, and gulls $(\mathrm{n}=2)$, and from the environment $(\mathrm{n}=4)$. Samples were collected on James Ross Island $(\mathrm{n}=25)$, Seymour Island ( $\mathrm{n}=13)$, Antarctica, and Isla Magdalena, Patagonia $(\mathrm{n}=3)$ (Table S1). In addition to the 37 isolates, which were classified as $E$. coli species using both commercial biochemical kits, four isolates were classified as "atypical/inactive" E. coli (9.7\%). Compared to the other $E$. coli species, the four isolates were beta-glucuronidase negative and unable to ferment sorbitol and melibiose (data not shown).

The 16S rDNA region (1,352 out of 1,494 bp) in all 41 Escherichia isolates was analyzed. While 37 isolates showed $99.5-99.8 \%$ nucleotide sequence similarity to the 16S rDNA sequence of E. coli (E. coli type strain; GenBank Accession No. X80725), the $16 \mathrm{~S}$ rDNA sequences of the four above mentioned isolates, previously characterized using commercial tests as atypical/inactive $E$. coli (P4652, P4653, P4740 and P5661), showed the greatest similarity (99.6-99.7\%) to the 16S rDNA sequence of $E$. albertii (E. albertii type strain; GenBank Accession No. AJ508775). Three of the E. albertii isolates were obtained from seal feces (James Ross Island, Antarctica) and one E. albertii isolate came from the feces of a penguin (Isla Magdalena, Patagonia) (Table 1).

To confirm the classification of E. albertii based on $16 \mathrm{~S}$ rDNA sequencing, two DNA fingerprinting techniques, automated ribotyping and rep-PCR were used to show the differences between the isolates and their similarity to related Escherichia spp. The results of both methods clearly grouped isolates P4652, P4653, P4740, and P5661 with the E. albertii CCM $7160^{\mathrm{T}}$ type strain (Fig. 1). Moreover, PFGE of $\mathrm{XbaI}$ restriction fragments revealed identical fingerprints for isolates $\mathrm{P} 4652$ and $\mathrm{P} 4653$, suggesting that these two isolates are representatives of the same clone (Fig. 2). The P4652 isolate was deposited in the Czech Collection of Microorganisms (Brno, Czech Republic), under accessional number CCM 8505, as a representative of E. albertii strains isolated from seals in Antarctica.

\section{Comparison of Antarctic isolates to previously characterized E. albertii isolates}

Based on a genome-wide analysis of 34 E. albertii strains isolated from 3 different geographic areas (Japan, Germany, and Brazil) and from 3 different hosts (humans, birds, and cats), E. albertii can be further divided into five different phylogroups (G1G5), as recently described [37]. We compared six concatenated housekeeping gene sequences from E. albertii isolates examined 
A)
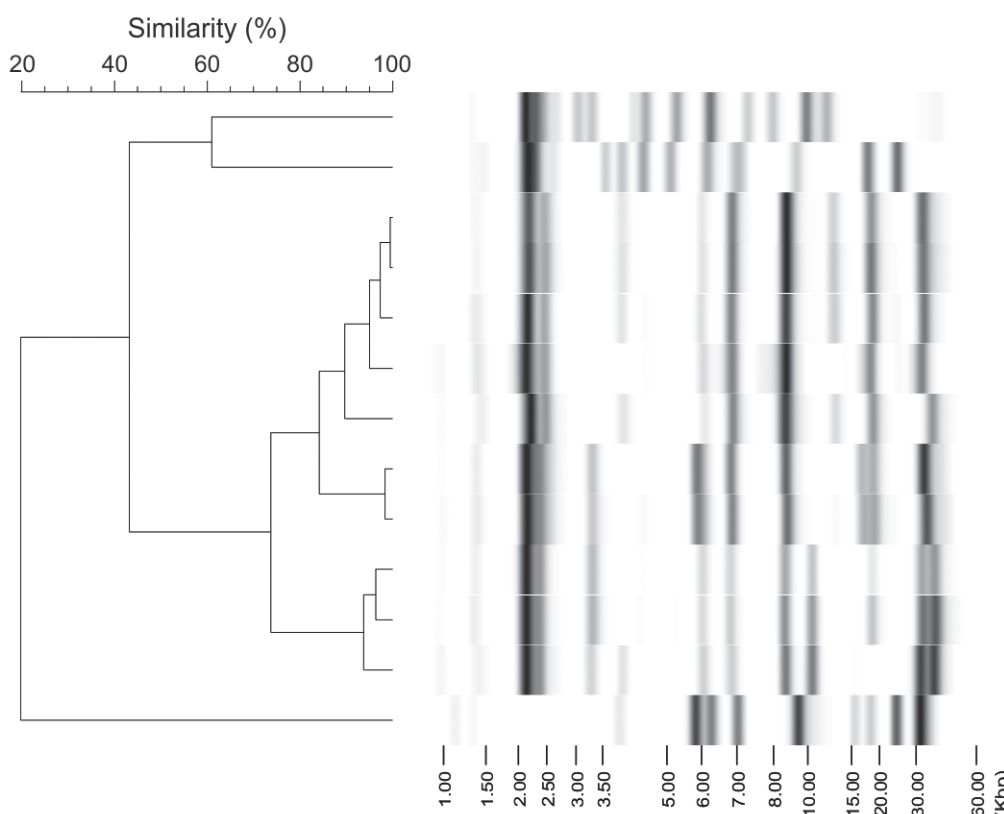

$\begin{array}{ll}\text { CCM } 3667 & \text { E. hermannii } \\ \text { CCM } 4034 & \text { E. fergusonii } \\ \mathrm{P} 4652 \text { (=CCM 8505) } & \text { E. albertii } \\ \mathrm{P} 4653 & \text { E. albertii } \\ \mathrm{P} 4740 & \text { E. albertii } \\ \mathrm{CCM} 7160^{\top} & \text { E. albertii } \\ \mathrm{P} 5661 & \text { E. albertii } \\ \mathrm{P} 4656 & \text { E. coli } \\ \mathrm{P} 4657 & \text { E. coli } \\ \mathrm{P} 4664 & \text { E. coli } \\ \mathrm{P} 4665 & \text { E. coli } \\ \text { CCM 5172 } & \text { E. coli } \\ \text { CCM 3682 } & \text { E. vulneris }\end{array}$

B)
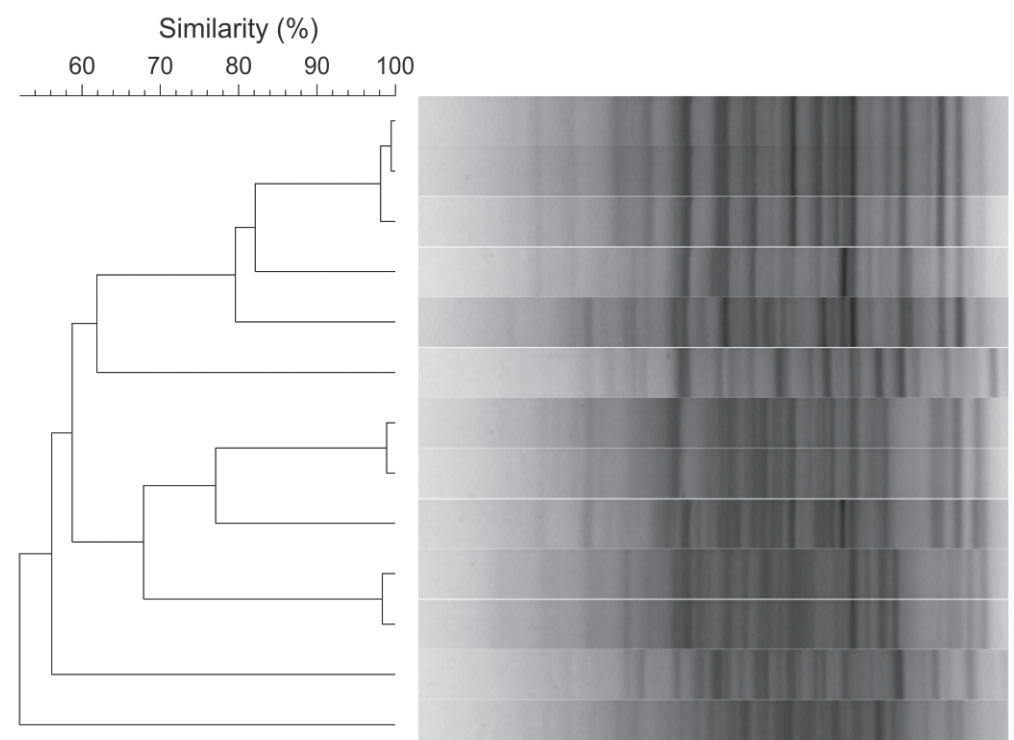

P4652 (=CCM 8505) E. albertii

P4653

E. albertii

$\mathrm{P} 4740$

E. albertii

P5661

E. albertii

CCM $7160^{\top}$

E. albertii

CCM 3667

E. hermannii

P4664

E. coli

P4665

E. coli

CCM 5172

E. coli

P4656

E. coli

P4657

E. coli

CCM 3682

E. vulneris

CCM 4034

E. fergusonii

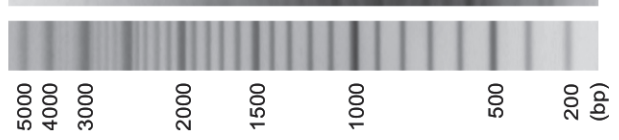

Molecular Size Marker

Fig. 1. Dendrograms based on cluster analysis of A) ribotype profiles and B) rep-PCR fingerprints. Four strains previously identified as $E$. albertii by $16 \mathrm{~S}$ rDNA analysis (P4661, P4652, $\mathrm{P} 4653$ and $\mathrm{P} 4740$ ) were used as well as strain CCM $7160^{\mathrm{T}}$ (type strain of E. albertii), strain CCM $5172^{\mathrm{T}}$ (type strain of E. coli), four randomly selected strains examined in this study previously identified as E. coli by $16 \mathrm{~S}$ rDNA analysis (P4656, P4657, $\mathrm{P} 4664$ and $\mathrm{P} 4665$; Table 1) and E. vulneris, E. hermanni and E. fergusonii reference strains as outgroups.

in this study (with a total length of 2,040 bp) to corresponding sequences present in the 34 draft genomes examined in [37]. While penguin isolate P5661 was completely identical to the silver heron isolate (Egretta garzetta) sampled in Japan (NIAH_Bird_8, GeneBank Accession No. BBVQ01000001-BBVQ01000167), seal isolates P4652, P4653 and P4740 were most similar (99.99\% of sequence identity) to a raven isolate (Corvus sp.) found in Japan (E2675, GeneBank Accession No. BBVT01000001BBVT01000119). All Antarctic isolates were genetically most similar to the members of phylogroup G3 (99.99\% of sequence identity and more) and shared less than $99 \%$ of sequence identity with samples from other phylogroups. 


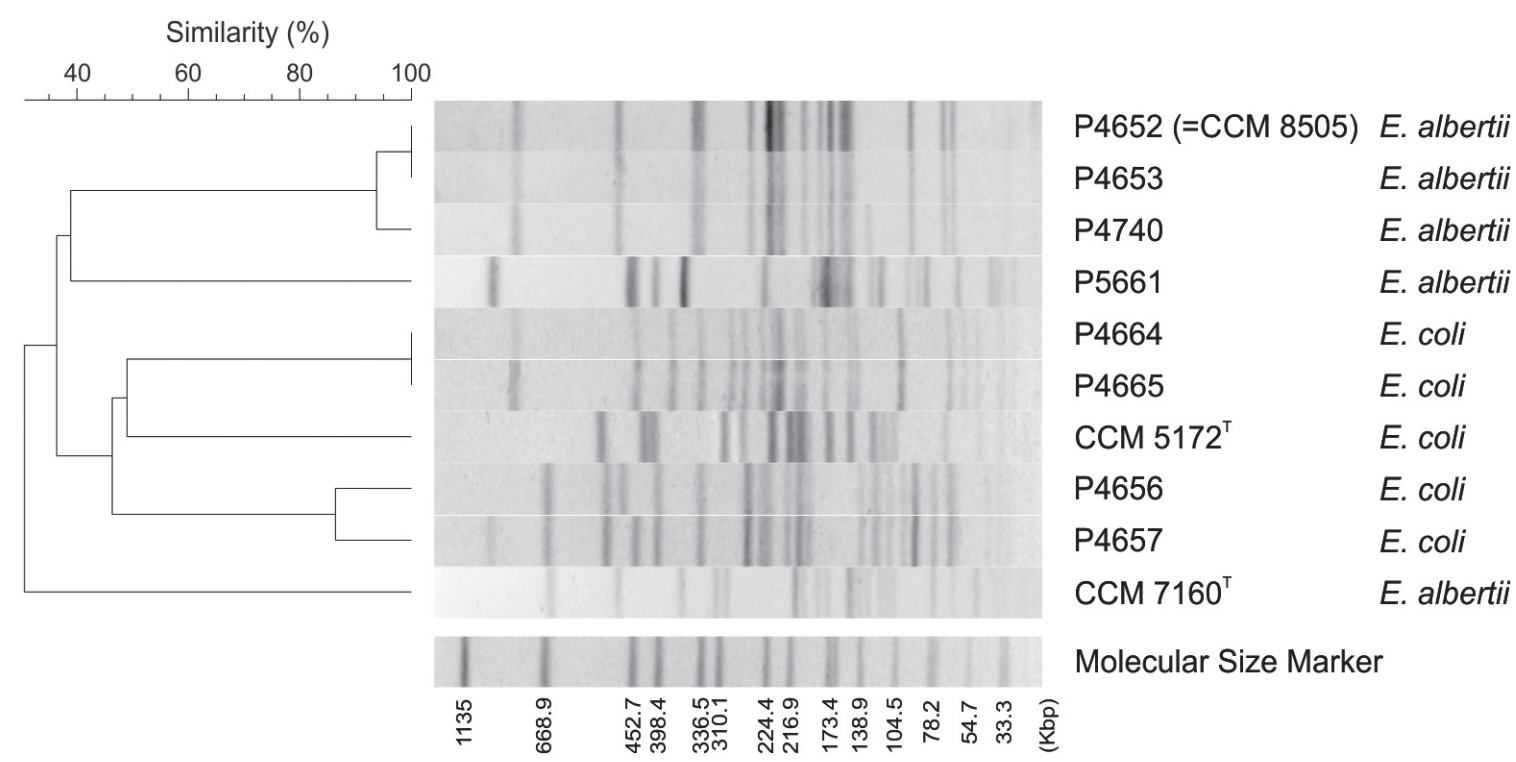

Fig. 2. PFGE dendrogram based on cluster analysis of macro-restriction patterns obtained from investigated E. albertii and E. coli strains. Four E. albertii isolates (P4661, P4652, P4653 and P4740) were used as well as strain CCM $7160^{\mathrm{T}}$ (type strain of E. albertii), strain CCM $5172^{\mathrm{T}}$ (type strain of $E$. coli), and four randomly selected strains examined in this study previously identified as E. coli by 16S rDNA analysis (P4656, P4657, P4664 and P4665; Table 1).

\section{Other characteristics of E. albertii identified in this study}

Detection of virulence determinants: Out of 21 tested virulence factor determinants (see Material and Methods section), all isolates were PCR positive for subunit B of cytolethal distending toxin (CDT, $c d t \mathrm{~B}$ ) and intimin (eae). In addition, the aerobactin determinant (aer) was found in P5661, type I fimbriae (fimA) in P4740 and P5661, invasion plasmid antigen $\mathrm{H}$ (ipaH) in P5661, and the aerobactin iron transport system (iucC) in P4652, P4653 and P4740 (Table 1).

Production of antimicrobial agents: While Escherichia albertii type strain CCM $7160^{\mathrm{T}}$ did not produced bacteriocins or phages, Antarctic and Patagonian E. albertii isolates inhibited the growth of indicator strains E. coli and S. sonnei. Using PCR screening, the presence of 32 determinants of known bacteriocin types (i.e. 25 colicin and 7 microcin determinants) was screened and four different bacteriocin types were identified. While colicin D and E7 determinants were found in E. albertii isolated from seals in Antarctica, the penguin isolate from Patagonia contained determinants encoding colicins B and M (Table 1).

Analyses of bacterial extracts activity on human cells: Since we detected DNA sequences encoding CDT in all E. albertii isolates, which has been found to affect the cell cycle [4, 8, 16, 40,60], we analyzed cell cycles of human malignant melanoma A375 cells treated with protein extracts from E. albertii isolates (P4652, P4653, P4740 and P5661). Unlike the 'control' E. coli $\mathrm{K} 12$ protein extract, extracts from E. albertii isolates as well as lysates from positive controls (E. albertii type strain $C C M 7160^{\mathrm{T}}$ ) caused accumulation of A375 cells in G2/M transition after 24 and $48 \mathrm{hr}$ of treatment (Fig. 3).

\section{DISCUSSION}

Escherichia albertii is considered to be a food-borne pathogen of the human gastrointestinal tract that causes gastroenteritis around the word (Table 2). In this study, we identified three strains of E. albertii in feces of seals on James Ross Island, Antarctica, and one strain in feces of a penguin on Isla Magdalena, Patagonia, as E. albertii species, using three independent diagnostic tools-16S rDNA sequencing, ribotyping, and rep-PCR.

According to the analyses of six housekeeping genes ( $\operatorname{ssp} \mathrm{C}, \operatorname{clp\mathrm {X}}, f a d \mathrm{D}, i c d \mathrm{~A}, y_{s} \mathrm{P}$ and $\left.m d h\right)$, all examined E. albertii isolates were most similar to the members of phylogroup G3, described in [37]. However, until now, no associations of group G3 and bacterial hosts, with infectious symptoms and geographic areas, have been described [37].

E. albertii isolates are often classified as atypical enteropathogenic E. coli (aEPEC). This classification is based on the fact that both groups share a specific set of virulence genes including intimin encoding genes located within the LEE pathogenicity island $[45,58]$. Unlike EPEC, E. albertii often encodes cytolethal distending toxin. The gene encoding subunit B of CDT (cdtB) was detected in all $E$. albertii isolates examined in this study. There are few other bacterial genotoxins; to date, in addition to CDTs, we have the uropathogenic-specific protein (usp) and colibactin [4]. Above mentioned results are in concordance with our results showing that Antarctic and Patagonia E. albertii whole protein extracts blocked cell cycles in the G2/M phase. Since we detected the $c d t \mathrm{~B}$ subunit in the bacterial DNA and did not find any other DNA determinants coding known genotoxins ( $u s p$ or colibactin), we propose that the cell cycle arrest was caused by CDTs. Except of eae and $c d t \mathrm{~B}$ determinants, genes encoding other virulence factors including aerobactin synthesis (aer) and aerobactin iron transport system (iucC), and fimbriae type I (fimA) were detected. 


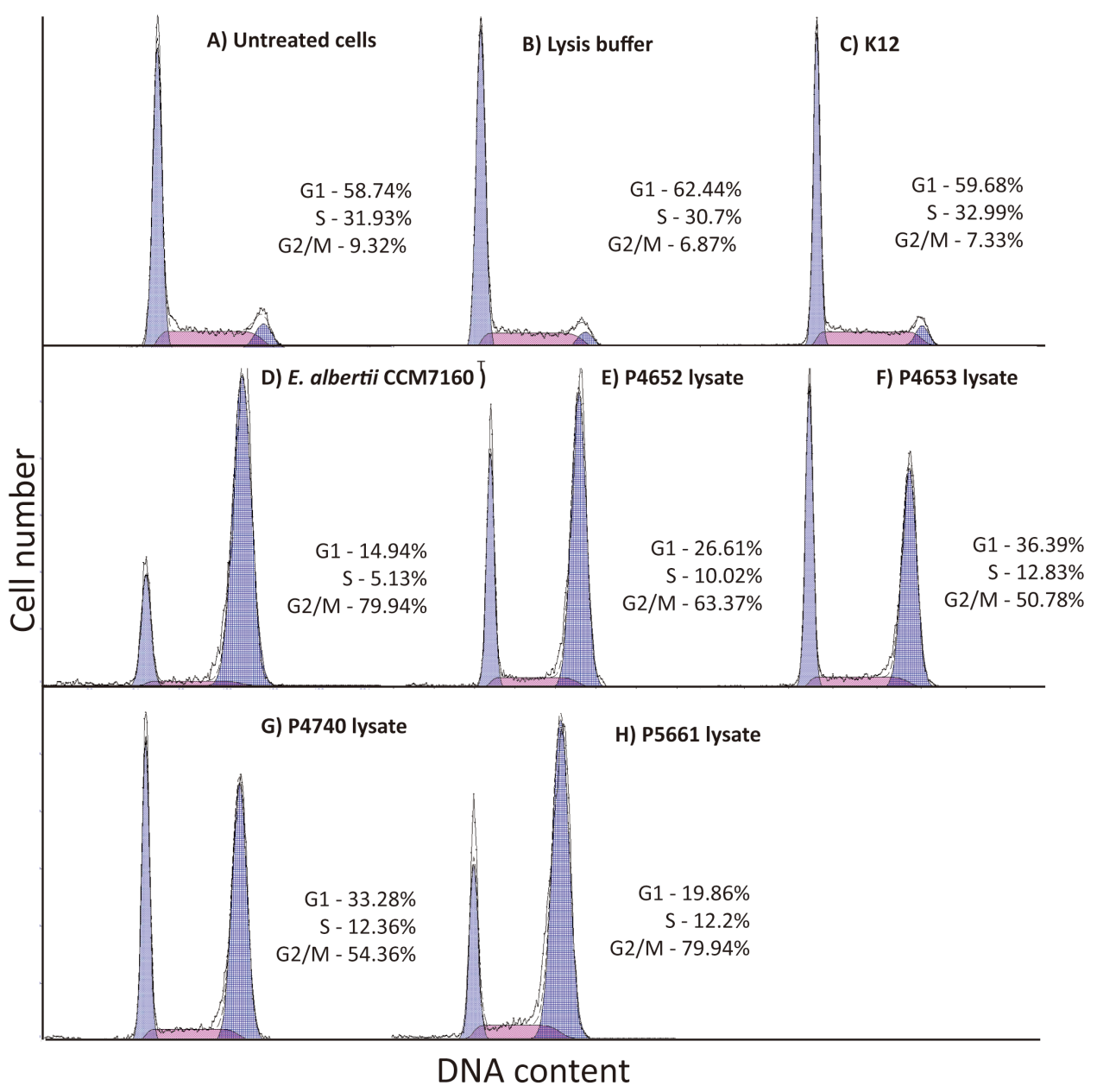

Fig. 3. Cell cycle analysis. All negative controls: non-treated cells (A), cells treated with bacterial lysis buffer (B) and lysate from E. coli K12 (non-producing strain; C), did not affect cell cycle of cell line A375, and showed normal distribution of phases. Whole protein extract from $E$. albertii type strain CCM $7160^{\mathrm{T}}$ (CDT producing strain; D) [16] and extracts from PCR cdtB-positive E. albertii isolates (P4652, $\mathrm{P} 4653$, $\mathrm{P} 4740$ and P5661; E-H) caused cell cycle arrest and accumulation of A375 cells in G2/M transition. Only results after $48 \mathrm{hr}$ of treatment are shown.

In addition, the large invasive plasmid (detected by presence of ipaH), typical for all virulent Shigella and enteroinvasive E. coli (EIEC) isolates, was found.

The frequency of bacteriocin determinants in pathogenic E. coli isolates is higher compared to commensal E. coli [12, 18, 27, $30,48,51]$. In our study, all four identified $E$. albertii were found to be bacteriocin double-producers (Table 1), encoding colicins $\mathrm{B}, \mathrm{D}, \mathrm{E} 7$, and M. Interestingly, E. albertii type strain CCM $7160^{\mathrm{T}}$, which was also included in our bacteriocin detection assay, did not produce any tested antimicrobial substances. Production of colicin D is extremely rare in human E. coli strains. Occurrence of the colicin D determinant among extraintestinal pathogenic E. coli (ExPEC) isolates have revealed two colicin D producers among 407 examined strains (0.5\%) [29] and similar analysis among fecal strains of E. coli only identified one colicin D determinant among 1,283 examined strains (0.08\%) [29]. Similarly, frequency of E7 production in human E. coli was shown to be quite low $(0.6-2.3 \%)[12,27,29]$. On the other hand, colicins B and $\mathrm{M}$ are known to be encoded on large plasmids, which are present in many E. coli, including commensal (1.1-8.6\%) [12, 28], uropathogenic (4.1-12.8\%) [7, 49], and other ExPEC (5.0-11.7\%) [27, 29]. However, the presence of rare colicin determinants among tested $E$. albertii isolates may correspond to the geographical differences between the tested E. albertii and E. coli strains [48].

Isolates P4652 and P4653, which came from the different seal feces collected on the same day at small beach nearby Lachman Cape, James Ross Island, Antarctica, shared the following four characteristics: (1) identical 16S rDNA sequences, (2) same sequences of six housekeeping genes $(a s p \mathrm{C}, c l p \mathrm{X}, f a d \mathrm{D}, i c d \mathrm{~A}, l y s \mathrm{P}$ and $m d h)$, (3) identical ribotype, rep-PCR, and PFGE profiles, and (4) harbored same virulence factors and bacteriocin determinants (Table 1, Figs. 1 and 2). These facts imply that P4652 and $\mathrm{P} 4653$ are isolates of the same strain obtained from different faeces of one seal. Antarctic seal isolate P4740 had different ribotype, rep-PCR, and PFGE profiles compared to the P4652 and P4653 isolates. However, P4740 was shown to be phylogenetically related to the P4652 and P4653 isolates, since it possessed identical 16S rDNA sequences, identical sequences of six housekeeping genes, and the presence of identical bacteriocin determinants as the P4652 and P4653 isolates. On the other hand, isolate P5661 was found 
Table 2. Strains of E. albertii published since 2003

\begin{tabular}{|c|c|c|c|c|c|}
\hline No. of isolates & Host & Geographic area & Clinical impact & Year of isolation & Reference \\
\hline 5 & Human & Bangladesh & Diarrhea & 1990-1991 & {$[15]$} \\
\hline 21 & Human & Bangladesh & Diarrhea & $1990-1993$ & {$[52]$} \\
\hline 1 & Drinking water in hospital & Hungary & NA & 2005 & [9] \\
\hline 7 & Birds & U.S.A. & Death & 2005-2007 & {$[33]$} \\
\hline 2 & Birds & Canada & Healthy & 2005 & {$[33]$} \\
\hline 5 & Birds & Scotland & Death & 1998-2000 & {$[20]$} \\
\hline 9 & Birds & Australia & Healthy & 2001-2002 & {$[33]$} \\
\hline 3 & Human & Guinea-Bissau & Healthy & 1997 & {$[56]$} \\
\hline 2 & Human & U.S.A. & Diarrhea & NA & [33] \\
\hline 7 & Birds & Australia & NA & NA & [57] \\
\hline 9 & Birds & Korea & Healthy & 2009-2010 & [34] \\
\hline 6 & Human & Japan & Gastroenteritis & 2011 & {$[35]$} \\
\hline 1 & Environmental fresh water & Bangladesh & NA & 2006 & {$[42]$} \\
\hline 1 & Human & Poland & Diarrhea & NA & {$[10]$} \\
\hline 6 & Human & Japan & Diarrhea & 2003 & {$[2]$} \\
\hline 1 & Swine & Japan & Healthy & 2004 & {$[14]$} \\
\hline 18 & Environmental water & Canada & NA & 2009 & {$[25]$} \\
\hline 27 & Chicken carcass & U.S.A. & NA & 2009-2010 & {$[21]$} \\
\hline 39 & Human & Norway & Diarrhea & $2008-2014$ & {$[6]$} \\
\hline 2 & Chicken food & Japan & NA & 2014 & {$[24]$} \\
\hline 1 & Raw chicken liver & Japan & NA & 2013 & {$[3]$} \\
\hline 14 & Human & Japan, Germany, Brazil & Gastroenteritis & 1993-2009 & {$[35]$} \\
\hline 11 & Bird & Japan & NA & 1993-2009 & {$[35]$} \\
\hline 1 & Cat & Brazil & Healthy & 2004 & {$[31]$} \\
\hline 48 & Human & NA & Diarrhea & $1997-2007$ & {$[32]$} \\
\hline 30 & Raw meat (duck, chicken, mutton) & China & NA & NA & {$[58]$} \\
\hline 3 & Human & Japan & NA & $2008-2009$ & {$[37]$} \\
\hline 1 & Human & Australia & Febrile infection & NA & {$[17]$} \\
\hline 1 & Human & Japan & Diarrhea & 2008 & {$[13]$} \\
\hline
\end{tabular}

NA; not available.

to be distantly related based on its $16 \mathrm{~S}$ rDNA sequence, MLST data, ribotyping result, rep-PCR and PFGE profile as well as the presence of different virulence factors and bacteriocin determinants (Table 1 and Figs. 1 and 2). However, since P5661 was isolated from a penguin in Patagonia, the observed differences could simply reflect host and geographical differences.

ACKNOWLEDGMENTS. The authors want to thank the staff of the J.G. Mendel Czech Antarctic Station for their assistance (part of the Czech Polar Research Infrastructure (CzechPolar2), supported by the Ministry of Education, Youth and Sports of the Czech Republic (LM2015078)). Additional support was provided by the Grant Agency of the Czech Republic to DS (16-21649S), by the National Sustainability Program of the Czech Ministry of Education, Youth and Sports (MEYS, CETOCOEN, LO1214) and by founds from the Faculty of Medicine, Masaryk University (ROZV/25/LF/2017) to junior researcher Juraj Bosák. We also thank to Thomas Secrest (Secrest Editing, Ltd.) for English editing of the manuscript.

\section{REFERENCES}

1. Albert, M. J., Alam, K., Islam, M., Montanaro, J., Rahaman, A. S., Haider, K., Hossain, M. A., Kibriya, A. K. and Tzipori, S. 1991. Hafnia alvei, a probable cause of diarrhea in humans. Infect. Immun. 59: 1507-1513. [Medline]

2. Asoshima, N., Matsuda, M., Shigemura, K., Honda, M., Yoshida, H., Oda, T. and Hiwaki, H. 2015. Isolation of Escherichia albertii from Raw Chicken Liver in Fukuoka City, Japan. Jpn. J. Infect. Dis. 68: 248-250. [Medline] [CrossRef]

3. Asoshima, N., Matsuda, M., Shigemura, K., Honda, M., Yoshida, H., Hiwaki, H., Ogata, K. and Oda, T. 2014. Identification of Escherichia albertii as a causative agent of a food-borne outbreak occurred in 2003. Jpn. J. Infect. Dis. 67: 139-140. [Medline] [CrossRef]

4. Bezine, E., Vignard, J. and Mirey, G. 2014. The cytolethal distending toxin effects on Mammalian cells: a DNA damage perspective. Cells 3: 592-615. [Medline] [CrossRef]

5. Birosová, E., Siegfried, L., Kmet’ová, M., Makara, A., Ostró, A., Gresová, A., Urdzík, P., Liptáková, A., Molokácová, M., Bártl, R. and Valanský, L. 2004. Detection of virulence factors in alpha-haemolytic Escherichia coli strains isolated from various clinical materials. Clin. Microbiol. Infect. 10: 569-573. [Medline] [CrossRef]

6. Brandal, L. T., Tunsjø, H. S., Ranheim, T. E., Løbersli, I., Lange, H. and Wester, A. L. 2015. Shiga toxin 2a in Escherichia albertii. J. Clin. Microbiol. 53: 1454-1455. [Medline] [CrossRef]

7. Budič, M., Rijavec, M., Petkovšek, Z. and Zgur-Bertok, D. 2011. Escherichia coli bacteriocins: antimicrobial efficacy and prevalence among 
isolates from patients with bacteraemia. PLoS One 6: e28769. [Medline] [CrossRef]

8. Comayras, C., Tasca, C., Pérès, S. Y., Ducommun, B., Oswald, E. and De Rycke, J. 1997. Escherichia coli cytolethal distending toxin blocks the HeLa cell cycle at the G2/M transition by preventing cdc2 protein kinase dephosphorylation and activation. Infect. Immun. 65: 5088-5095. [Medline]

9. Felföldi, T., Heéger, Z., Vargha, M. and Márialigeti, K. 2010. Detection of potentially pathogenic bacteria in the drinking water distribution system of a hospital in Hungary. Clin. Microbiol. Infect. 16: 89-92. [Medline] [CrossRef]

10. Fiedoruk, K., Daniluk, T., Swiecicka, I., Murawska, E., Sciepuk, M. and Leszczynska, K. 2014. First Complete Genome Sequence of Escherichia albertii Strain KF1, a New Potential Human Enteric Pathogen. Genome Announc. 2: 2. [Medline] [CrossRef]

11. Gillor, O., Giladi, I. and Riley, M. A. 2009. Persistence of colicinogenic Escherichia coli in the mouse gastrointestinal tract. BMC Microbiol. 9: 165 . [Medline] [CrossRef]

12. Gordon, D. M. and O'Brien, C. L. 2006. Bacteriocin diversity and the frequency of multiple bacteriocin production in Escherichia coli. Microbiology 152: 3239-3244. [Medline] [CrossRef]

13. Hinenoya, A., Yasuda, N., Hibino, T., Shima, A., Nagita, A., Tsukamoto, T. and Yamasaki, S. 2017. Isolation and Characterization of an Escherichia albertii Strain Producing Three Different Toxins from a Child with Diarrhea. Jpn. J. Infect. Dis. 70: 252-257. [Medline] [CrossRef]

14. Hinenoya, A., Shima, K., Asakura, M., Nishimura, K., Tsukamoto, T., Ooka, T., Hayashi, T., Ramamurthy, T., Faruque, S. M. and Yamasaki, S. 2014. Molecular characterization of cytolethal distending toxin gene-positive Escherichia coli from healthy cattle and swine in Nara, Japan. BMC Microbiol. 14: 97. [Medline] [CrossRef]

15. Huys, G., Cnockaert, M., Janda, J. M. and Swings, J. 2003. Escherichia albertii sp. nov., a diarrhoeagenic species isolated from stool specimens of Bangladeshi children. Int. J. Syst. Evol. Microbiol. 53: 807-810. [Medline] [CrossRef]

16. Hyma, K. E., Lacher, D. W., Nelson, A. M., Bumbaugh, A. C., Janda, J. M., Strockbine, N. A., Young, V. B. and Whittam, T. S. 2005. Evolutionary genetics of a new pathogenic Escherichia species: Escherichia albertii and related Shigella boydii strains. J. Bacteriol. 187: 619-628. [Medline] [CrossRef]

17. Inglis, T. J. J., Merritt, A. J., Bzdyl, N., Lansley, S. and Urosevic, M. N. 2015. First bacteraemic human infection with Escherichia albertii. New Microbes New Infect. 8: 171-173. [Medline] [CrossRef]

18. Kohoutová, D., Šmajs, D., Morávková, P., Cyrany, J., Morávková, M., Forstlová, M., Cihák, M., Rejchrt, S. and Bureš, J. 2014. Escherichia coli strains of phylogenetic group B2 and D and bacteriocin production are associated with advanced colorectal neoplasia. BMC Infect. Dis. $14: 733$. [Medline] [CrossRef]

19. Kuhnert, P., Hacker, J., Mühldorfer, I., Burnens, A. P., Nicolet, J. and Frey, J. 1997. Detection system for Escherichia coli-specific virulence genes: absence of virulence determinants in B and C strains. Appl. Environ. Microbiol. 63: 703-709. [Medline]

20. La Ragione, R. M., McLaren, I. M., Foster, G., Cooley, W. A. and Woodward, M. J. 2002. Phenotypic and genotypic characterization of avian Escherichia coli O86:K61 isolates possessing a gamma-like intimin. Appl. Environ. Microbiol. 68: 4932-4942. [Medline] [CrossRef]

21. Lindsey, R. L., Fedorka-Cray, P. J., Abley, M., Turpin, J. B. and Meinersmann, R. J. 2015. Evaluating the occurrence of Escherichia albertii in chicken carcass rinses by PCR, Vitek analysis, and sequencing of the rpoB gene. Appl. Environ. Microbiol. 81: 1727-1734. [Medline] [CrossRef]

22. López-Saucedo, C., Cerna, J. F., Villegas-Sepulveda, N., Thompson, R., Velazquez, F. R., Torres, J., Tarr, P. I. and Estrada-García, T. 2003. Single multiplex polymerase chain reaction to detect diverse loci associated with diarrheagenic Escherichia coli. Emerg. Infect. Dis. 9: 127-131. [Medline] [CrossRef]

23. Luo, C., Walk, S. T., Gordon, D. M., Feldgarden, M., Tiedje, J. M. and Konstantinidis, K. T. 2011. Genome sequencing of environmental Escherichia coli expands understanding of the ecology and speciation of the model bacterial species. Proc. Natl. Acad. Sci. U.S.A. 108: $7200-7205$. [Medline] [CrossRef]

24. Maeda, E., Murakami, K., Sera, N., Ito, K. and Fujimoto, S. 2015. Detection of Escherichia albertii from chicken meat and giblets. J. Vet. Med. Sci. 77: 871-873. [Medline] [CrossRef]

25. Maheux, A. F., Boudreau, D. K., Bergeron, M. G. and Rodriguez, M. J. 2014. Characterization of Escherichia fergusonii and Escherichia albertii isolated from water. J. Appl. Microbiol. 117: 597-609. [Medline] [CrossRef]

26. Martínez, J. L., Herrero, M. and de Lorenzo, V. 1994. The organization of intercistronic regions of the aerobactin operon of pColV-K30 may account for the differential expression of the iucABCD iutA genes. J. Mol. Biol. 238: 288-293. [Medline] [CrossRef]

27. Micenková, L., Bosák, J., Vrba, M., Ševčíková, A. and Šmajs, D. 2016. Human extraintestinal pathogenic Escherichia coli strains differ in prevalence of virulence factors, phylogroups, and bacteriocin determinants. BMC Microbiol. 16: 218. [Medline] [CrossRef]

28. Micenková, L., Beňová, A., Frankovičová, L., Bosák, J., Vrba, M., Ševčíková, A., Kmet’ová, M. and Šmajs, D. 2017. Human Escherichia coli isolates from hemocultures: Septicemia linked to urogenital tract infections is caused by isolates harboring more virulence genes than bacteraemia linked to other conditions. Int. J. Med. Microbiol. 307: 182-189. [Medline] [CrossRef]

29. Micenková, L., Štaudová, B., Bosák, J., Mikalová, L., Littnerová, S., Vrba, M., Ševčíková, A., Woznicová, V. and Šmajs, D. 2014. Bacteriocinencoding genes and ExPEC virulence determinants are associated in human fecal Escherichia coli strains. BMC Microbiol. 14: 109. [Medline] [CrossRef]

30. Micenková, L., Bosák, J., Štaudová, B., Kohoutová, D., Čejková, D., Woznicová, V., Vrba, M., Ševčíková, A., Bureš, J. and Šmajs, D. 2016. Microcin determinants are associated with B2 phylogroup of human fecal Escherichia coli isolates. MicrobiologyOpen 5: 490-498. [Medline] [CrossRef]

31. Morato, E. P., Leomil, L., Beutin, L., Krause, G., Moura, R. A. and Pestana de Castro, A. F. 2009. Domestic cats constitute a natural reservoir of human enteropathogenic Escherichia coli types. Zoonoses Public Health 56: 229-237. [Medline] [CrossRef]

32. Nimri, L. F. 2013. Escherichia albertii, a newly emerging enteric pathogen with poorly defined properties. Diagn. Microbiol. Infect. Dis. 77: 91-95. [Medline] [CrossRef]

33. Oaks, J. L., Besser, T. E., Walk, S. T., Gordon, D. M., Beckmen, K. B., Burek, K. A., Haldorson, G. J., Bradway, D. S., Ouellette, L., Rurangirwa, F. R., Davis, M. A., Dobbin, G. and Whittam, T. S. 2010. Escherichia albertii in wild and domestic birds. Emerg. Infect. Dis. 16: 638-646. [Medline] [CrossRef]

34. Oh, J. Y., Kang, M. S., Hwang, H. T., An, B. K., Kwon, J. H. and Kwon, Y. K. 2011. Epidemiological investigation of eaeA-positive Escherichia coli and Escherichia albertii strains isolated from healthy wild birds. J. Microbiol. 49: 747-752. [Medline] [CrossRef]

35. Ooka, T., Tokuoka, E., Furukawa, M., Nagamura, T., Ogura, Y., Arisawa, K., Harada, S. and Hayashi, T. 2013. Human gastroenteritis outbreak associated with Escherichia albertii, Japan. Emerg. Infect. Dis. 19: 144-146. [Medline] [CrossRef]

36. Ooka, T., Seto, K., Kawano, K., Kobayashi, H., Etoh, Y., Ichihara, S., Kaneko, A., Isobe, J., Yamaguchi, K., Horikawa, K., Gomes, T. A. T., Linden, A., Bardiau, M., Mainil, J. G., Beutin, L., Ogura, Y. and Hayashi, T. 2012. Clinical significance of Escherichia albertii. Emerg. Infect. Dis. 18: 488-492. [Medline] [CrossRef] 
37. Ooka, T., Ogura, Y., Katsura, K., Seto, K., Kobayashi, H., Kawano, K., Tokuoka, E., Furukawa, M., Harada, S., Yoshino, S., Seto, J., Ikeda, T., Yamaguchi, K., Murase, K., Gotoh, Y., Imuta, N., Nishi, J., Gomes, T. A., Beutin, L. and Hayashi, T. 2015. Defining the Genome Features of Escherichia albertii, an Emerging Enteropathogen Closely Related to Escherichia coli. Genome Biol. Evol. 7: 3170-3179. [Medline]

38. Paciorek, J. 2002. Virulence properties of Escherichia coli faecal strains isolated in Poland from healthy children and strains belonging to serogroups O18, O26, O44, O86, O126 and O127 isolated from children with diarrhoea. J. Med. Microbiol. 51: 548-556. [Medline] [CrossRef]

39. Paton, A. W. and Paton, J. C. 1998. Detection and characterization of Shiga toxigenic Escherichia coli by using multiplex PCR assays for stx 1, stx2, eaeA, enterohemorrhagic E. coli hlyA, rfbO111, and rfbO157. J. Clin. Microbiol. 36: 598-602. [Medline]

40. Pickett, C. L., Cottle, D. L., Pesci, E. C. and Bikah, G. 1994. Cloning, sequencing, and expression of the Escherichia coli cytolethal distending toxin genes. Infect. Immun. 62: 1046-1051. [Medline]

41. Pontes, D. S., Pinheiro, F. A., Lima-Bittencourt, C. I., Guedes, R. L. M., Cursino, L., Barbosa, F., Santos, F. R., Chartone-Souza, E. and Nascimento, A. M. A. 2009. Multiple antimicrobial resistance of gram-negative bacteria from natural oligotrophic lakes under distinct anthropogenic influence in a tropical region. Microb. Ecol. 58: 762-772. [Medline] [CrossRef]

42. Rahman, M. Z., Akter, S., Azmuda, N., Sultana, M., Weill, F. X., Khan, S. I., Grimont, P. A. D. and Birkeland, N. K. 2013. Serological crossreaction between O-antigens of Shigella dysenteriae type 4 and an environmental Escherichia albertii isolate. Curr. Microbiol. 67: 590-595. [Medline] [CrossRef]

43. Schmidt, H., Knop, C., Franke, S., Aleksic, S., Heesemann, J. and Karch, H. 1995. Development of PCR for screening of enteroaggregative Escherichia coli. J. Clin. Microbiol. 33: 701-705. [Medline]

44. Sedláček, I., Grillová, L., Kroupová, E., Černohlávková, J. and Šmajs, D. 2013. Escherichia albertii from feces of seals (Leptonychotes weddelli) in James Ross Island, Antarctica. Czech Polar Reports 3: 173-183. [CrossRef]

45. Sharma, M., Kniel, K. E., Derevianko, A., Ling, J. and Bhagwat, A. A. 2007. Sensitivity of Escherichia albertii, a potential food-borne pathogen, to food preservation treatments. Appl. Environ. Microbiol. 73: 4351-4353. [Medline] [CrossRef]

46. Shima, A., Hinenoya, A., Asakura, M., Sugimoto, N., Tsukamoto, T., Ito, H., Nagita, A., Faruque, S. M. and Yamasaki, S. 2012. Molecular characterizations of cytolethal distending toxin produced by Providencia alcalifaciens strains isolated from patients with diarrhea. Infect. Immun. 80: 1323-1332. [Medline] [CrossRef]

47. Slaninová, I., Brezinová, L., Koubíková, L. and Slanina, J. 2009. Dibenzocyclooctadiene lignans overcome drug resistance in lung cancer cells-study of structure-activity relationship. Toxicol. In Vitro 23: 1047-1054. [Medline] [CrossRef]

48. Šmajs, D., Cejková, D., Micenková, L., Lima-Bittencourt, C. I., Chartone-Souza, E., Šmarda, J. and Nascimento, A. M. A. 2012. Human Escherichia coli strains of different geographical and time source: bacteriocin types and their gene sequences are population-specific. Environ. Microbiol. Rep. 4: 459-466. [Medline] [CrossRef]

49. Šmajs, D., Micenková, L., Šmarda, J., Vrba, M., Sevčíková, A., Vališová, Z. and Woznicová, V. 2010. Bacteriocin synthesis in uropathogenic and commensal Escherichia coli: colicin E1 is a potential virulence factor. BMC Microbiol. 10: 288. [Medline] [CrossRef]

50. Šmajs, D., Strouhal, M., Matejková, P., Cejková, D., Cursino, L., Chartone-Souza, E., Šmarda, J. and Nascimento, A. M. A. 2008. Complete sequence of low-copy-number plasmid MccC7-H22 of probiotic Escherichia coli $\mathrm{H} 22$ and the prevalence of mcc genes among human E. coli. Plasmid 59: 1-10. [Medline] [CrossRef]

51. Štaudová, B., Micenková, L., Bosák, J., Hrazdilová, K., Slaninková, E., Vrba, M., Ševčíková, A., Kohoutová, D., Woznicová, V., Bureš, J. and Šmajs, D. 2015. Determinants encoding fimbriae type 1 in fecal Escherichia coli are associated with increased frequency of bacteriocinogeny. BMC Microbiol. 15: 201. [Medline] [CrossRef]

52. Stock, I., Rahman, M., Sherwood, K. J. and Wiedemann, B. 2005. Natural antimicrobial susceptibility patterns and biochemical identification of Escherichia albertii and Hafnia alvei strains. Diagn. Microbiol. Infect. Dis. 51: 151-163. [Medline] [CrossRef]

53. Švec, P., Nováková, D., Zácková, L., Kukletová, M. and Sedlácek, I. 2008. Evaluation of (GTG)5-PCR for rapid identification of Streptococcus mutans. Antonie van Leeuwenhoek 94: 573-579. [Medline] [CrossRef]

54. Švec, P., Černohlávková, J., Busse, H. J., Vojtková, H., Pantůček, R., Cnockaert, M., Mašlaňová, I., Králová, S., Vandamme, P. and Sedláček, I. 2015. Classification of strain CCM $4446^{\mathrm{T}}$ as Rhodococcus degradans sp. nov. Int. J. Syst. Evol. Microbiol. 65: 4381-4387. [Medline] [CrossRef]

55. Valentiner-Branth, P., Steinsland, H., Fischer, T. K., Perch, M., Scheutz, F., Dias, F., Aaby, P., Mølbak, K. and Sommerfelt, H. 2003. Cohort study of Guinean children: incidence, pathogenicity, conferred protection, and attributable risk for enteropathogens during the first 2 years of life. J. Clin. Microbiol. 41: 4238-4245. [Medline] [CrossRef]

56. Walk, S. T., Alm, E. W., Gordon, D. M., Ram, J. L., Toranzos, G. A., Tiedje, J. M. and Whittam, T. S. 2009. Cryptic lineages of the genus Escherichia. Appl. Environ. Microbiol. 75: 6534-6544. [Medline] [CrossRef]

57. Wang, H., Li, Q., Bai, X., Xu, Y., Zhao, A., Sun, H., Deng, J., Xiao, B., Liu, X., Sun, S., Zhou, Y., Wang, B., Fan, Z., Chen, X., Zhang, Z., Xu, J. and Xiong, Y. 2016. Prevalence of eae-positive, lactose non-fermenting Escherichia albertii from retail raw meat in China. Epidemiol. Infect. 144: 45-52. [Medline] [CrossRef]

58. Yamamoto, D., Hernandes, R. T., Liberatore, A. M. A., Abe, C. M., Souza, R. B., Romão, F. T., Sperandio, V., Koh, I. H. and Gomes, T. A. T. 2017. Escherichia albertii, a novel human enteropathogen, colonizes rat enterocytes and translocates to extra-intestinal sites. PLOS ONE 12: e0171385. [Medline] [CrossRef]

59. Yamamoto, S., Terai, A., Yuri, K., Kurazono, H., Takeda, Y. and Yoshida, O. 1995. Detection of urovirulence factors in Escherichia coli by multiplex polymerase chain reaction. FEMS Immunol. Med. Microbiol. 12: 85-90. [Medline] [CrossRef]

60. Young, V. B., Knox, K. A. and Schauer, D. B. 2000. Cytolethal distending toxin sequence and activity in the enterohepatic pathogen Helicobacter hepaticus. Infect. Immun. 68: 184-191. [Medline] [CrossRef] 